\title{
Cash Flow Statement: Assesment of Situation and Application problems in Serbia
}

\author{
Article history: \\ Received: 14 August 2014 \\ Sent for revision: 1 September 2014 \\ Received in revised form: 29 October 2014 \\ Accepted: 5 November 2014 \\ Available online: 23 December 2014
}

\begin{abstract}
Time of global economic crisis and unstable financial markets additionally emphasized the fact that inadequate cash flows are frequent serious problem in the operations of economic entities. With the aim to assess the situation and problems in application of cash flow statement and explain reasons of insufficient affirmation of cash flow statement in business practice in the Republic of Serbia, questionnaire based research was carried out among local companies. The questionnaire consisted of questions aimed at assessing the condition in the abovementioned problem and identifying causes of the recorded situation. The analysis of obtained data included identification of influence of the company size criterion. Obtained results point out that the quality of the preparation and analysis of cash flow statement are, for large companies, in general satisfactory, while for medium and small companies improvements are necessary regarding the existing practices and upgrading of knowledge related to the methodology of preparation of cash flow statement and cash flow analysis by managers and accountants.
\end{abstract}

Keywords: cash flow statement, Republic of Serbia, company size, situation, causes.

\section{Izveštaj o tokovima gotovine: stanje i problemi primene u Republici Srbiji}

Apstrakt: Vreme globalne ekonomske krize i nestabilnih finansijskih trižišta dodatno je potenciralo činjenicu da neadekvatni tokovi gotovine vrlo često predstavljaju ozbiljan problem u poslovanju privrednih subjekata. Sa ciljem da se sagleda stanje i problemi u primeni izveštaja o tokovima gotovine i objasni

\footnotetext{
${ }^{1}$ Foundation "Center for young talents", Novi Sad, dragmil67@gmail.com 
Miletić D.: Cash Flow Statement: Assesment of Situation and Application problems in..

zašto izveštaj o tokovima gotovine nije u dovoljnoj meri afirmisan u poslovnoj praksi u Republici Srbiji, sprovedeno je istraživanje na uzorku domaćih preduzeća putem upitnika. Upitnik se sastojao od pitanja usmerenih na utvrđivanje stanja navedenog problema i sagledavanja uzroka registrovanog stanja. Pitanja su analizirana sa stanovišta kriterijuma veličine pravnog lica. Na bazi analize dobijenih odgovora utvrđeno je da je kvalitet sastavljanja $i$ analize izveštaja o tokovima gotovine kod velikih pravnih lica uglavnom zadovoljavajući, dok je kod srednjih $i$ malih pravnih lica stanje nužno unaprediti što nalaže unapređenje postojeće prakse u domenu podizanja nivoa poznavanja metodologije sastavljanja izveštaja o tokovima gotovine $i$ cash flow analize od strane menadžera i sastavljača finansijskih izveštaja.

Ključne reči:izveštaj o tokovima gotovine, Republika Srbija, veličina privrednog subjekta, stanje, uzroci.

\section{Introduction}

Financial statements including balance sheet, income statement and cash flow statement are the base for estimation of financial performance of the companies. The importance of cash flow statement in comparison to the balance sheet and income statement is often underestimated (Lukač, 2013).

In developed economies, cash flow statement began to evolve long time ago from a retrospective document into the planning one, which is often prepared and designed for the internal needs of companies as an instrument for the financial performance monitoring and planning (Boussard \& Colasse, 1992).

In the international literature, dilemmas and considerations related to the cash flow statement (Broome, 2004), its meaning (Cheng \& Hollie, 2008) and methods of its preparation (Orpurt \& Zhang, 2009; Hales \& Orpurt, 2013) take an important place.

The emergence of financial crisis imposed to the managers at the global level, but also in the Republic of Serbia, the need for continuous assessments of the cash flows performance with upgrading of methodologies and incentives for successful cash flow management. In times of conjunctures and recession, in spite of realized profits, many companies face the difficulties of liabilities payment. Therefore, the cash as a factor of normal functioning and survival of companies during the crisis gains in importance, and cash flows monitoring and financial analysis turn into an important and essential part of comprehensive business analysis. The issues regarding the importance of cash and liquidity for companies in the times of crisis and necessity of financial survival are often emphasized in international academic literature (Ohlson \& Aier, 2009). 
Miletić D.: Cash Flow Statement: Assesment of Situation and Application problems in..

Due to presented situation research questions related to cash flow analysis increasingly appear as a focus of the research of the authors from the region. Vlaović et al. (2013) reviewed advantages and limitations of the discounted cash flows for evaluation of companies. Stevanović (2013) studied the classification of cash flows and dilemmas that emerge from it at the domestic and international levels, while Stevanović et al. (2013) discussed motivations and opportunities for creative cash flow reporting. Miletić (2011) conducted a comparison of direct and indirect methods of cash flow statement preparation. Some authors have carried out research focused on the cash flow reporting practices within certain industries such as mining (Slavković and Bugarin, 2011), or cement production (Đukić and Trajčevski, 2012). Trends of net income and free cash flow for individual stocks in the capital market in Bosnia \& Herzegovina were analyzed as well (Alihodžić, 2013).

For the majority of companies in Serbia cash flows statement is a mandatory part of the final account as a legal obligation for large, medium, and a number of small enterprises. However, in academic literature there is no evidence on extent to which the cash flow statement in Serbia is used in the analysis and planning of business operations, as well as whether in this respect there are some differences between companies depending on their size.

Research presented in this paper was carried out with the aim to examine the situation in the practice of preparation of cash flow statements among enterprises in Serbia, as well as to analyze the possible causes of the identified situation.

Assuming that in practice of preparation, analysis, implementation and auditing of cash flow statements the differences exist among legal entities depending on their size the basic null hypothesis was defined, and tested at the basis of the obtained research results:

$\mathrm{H}_{0}$ - There are no differences among enterprises of different size in Serbia regarding practice of preparation, analysis and auditing of cash flow statements.

This hypothesis was tested in regards to the assumptions that there are no differences regarding:

$\mathrm{H}_{01}$-the practice of preparation of cash flow statements throughout the year

$\mathrm{H}_{02}$ - the practice of preparation of planned and/or realized cash flow statements

$\mathrm{H}_{03}$ - the practice of utilization of different ratios in the cash flow analysis

$\mathrm{H}_{04}$-the frequency of audits of cash flow statements 
Miletić D.: Cash Flow Statement: Assesment of Situation and Application problems in..

\section{Research methodology}

The research was conducted based on a questionnaire to which business entities from the Republic of Serbia were invited to respond. The questions regarding the frequency of preparation of cash flow statement, the practices of preparation of the statements on planned and realized cash flows, the use of indicators to generate cash, liquidity and turnover, as well as the frequency of audits were included in order to get the information about the current situation related to cash flow analysis.

A series of questions directed to the understanding of the causes of the current situation regarding the preparation and utilization of a cash flow statement was also included. The importance of cash flow statement for managers, managers' incentives for creating a liquid asset structure, respondents' opinions regarding the position of cash flow statement in relation to other financial statements and estimation of the level, needs and opportunities for improvement of knowledge and skills related to cash flow statement preparation and utilization were among the analysed issues.

Representative sample invited to respond to the questionnaire consisted of 250 legal entities, among which companies of different size and from different sectors were evenly represented. The questionnaire was sent in the electronic form, it was anonymous, and the answers were used only for the research purposes.

The response rate was $21.60 \%$. Among the respondents, $43 \%$ were small, $33 \%$ medium and $24 \%$ large enterprises. Adequate representation of the different sizes of enterprises enabled analysis of possible differences in relation to preparation and utilization of the cash flow statement among legal entities of different size.

All major sectors that characterize the economic structure of the Republic of Serbia were represented: trade $(22.2 \%)$, manufacturing $(18.5 \%)$ and banking (11.1\%) dominated among respondents, but with significant shares agriculture (7.4\%), transport, information technology, tourism (5.6\%) and telecommunications (3.7\%) were also represented. The remaining $20.3 \%$ were enterprises from other business sectors.

Statistical analysis included frequency analysis of answers in the whole sample, as well as between companies classified by size into small, medium and large. Chi-square test of goodness of fit was used to test the statistical significances of differences in frequencies of individual responses between small, medium and large companies. Probabilities of nonexistence of differences regarding observed research question among enterprises of different size are given as the result of statistical analysis. If the probability of 
Miletić D.: Cash Flow Statement: Assesment of Situation and Application problems in..

the nonexistence of differences between enterprises of different sizes stated in the hypotheses is less than $p=0.05$ (95\% probability) or $p=0.01(99 \%$ probability), the alternative hypothesis can be accepted, i.e. that differences among companies of various sizes in regards to the observed aspect of preparation and utilization cash flow statements exist. Statistical software IBM SPSS Statistics 19 was used for the analysis.

\section{Results and Discussion}

In the first part their results related to screening of current practice in preparation and utilization of cash flow statement in the Republic of Serbia are discussed, followed with assessments of the causes of identified situation and identification of potential ways for improvement.

\subsection{Situation}

Screening of the situation in the preparation, utilization and auditing of the cash flow statement is based on analysis of frequencies of preparation of cash flow statements, the practice of preparation of the planned and actual cash flow statements, the frequency of utilization of different ratios related to cash flow, liquidity and turnover, as well as the frequency of audits.

The frequency of cash flows statement preparation throughout the financial year provides the insight in actual utilization of cash flow statement by the management, but also in the routine of cash flow statement preparation and analysis by the responsible accountants. Shares of companies that prepare cash flow statements regularly throughout the year depending on their size are presented in Table 1.

Table 1. The practice of cash flows statement preparation throughout the financial year $\left(p=0.149^{*}\right)$

\begin{tabular}{|c|c|c|c|}
\hline Company size & Prepare & Do not prepare & Not aware \\
\hline Small & $60.87 \%$ & $26.09 \%$ & $13.04 \%$ \\
\hline Medium & $66.67 \%$ & $22.22 \%$ & $11.11 \%$ \\
\hline Large & $84.62 \%$ & $7.69 \%$ & $7.69 \%$ \\
\hline Total & $\mathbf{6 8 . 5 2} \%$ & $\mathbf{2 0 . 3 7 \%}$ & $\mathbf{1 1 . 1 1 \%}$ \\
\hline *probability of nonexistence of differences among companies of different size \\
\hline
\end{tabular}

Source: Authors' calculation

The prevailing response that the cash flow statements are prepared throughout the year points out good practice. The trend of increase of share of companies preparing the cash flow statement throughout the year from small 
Miletić D.: Cash Flow Statement: Assesment of Situation and Application problems in..

towards large companies is clear and well expressed, in spite of the fact that the differences among companies of different size were not confirmed as statistically significant $(p=0.149)$. The fact that large and medium companies are required to submit their cash flow statement as a part of a set of financial statements contrary to majority of small companies should be kept in mind related to these findings. However, it is evident that among small companies there is a number of those that prepare cash flow statements for internal management purposes. Management of medium and especially of large companies has higher need for more complex financial reporting, with cash flow statement and financial indicators based on it as an essential part. Nevertheless, obtained results indicate that management of medium and small companies quite frequently uses cash flows statements throughout the financial year. However, the question of quality and interpretation of cash flow statements remains open.

The practice of preparation of planed and actual cash flow statements enables insight into relation of two alternative ways of utilization of cash flow statements: as a planning instrument, or just as an instrument for analysis of actual cash flows for the reporting period (Table 2).

Table 2. The practice of preparation planned and realized cash flow statements $\left(p=0.133^{*}\right)$

\begin{tabular}{|c|c|c|c|c|c|}
\hline Company size & Planned & Realized & Both & None & Not aware \\
\hline Small & $21.74 \%$ & $30.43 \%$ & $26.09 \%$ & $13.04 \%$ & $8.70 \%$ \\
\hline Medium & $11.11 \%$ & $38.89 \%$ & $33.33 \%$ & $0.00 \%$ & $16.67 \%$ \\
\hline Large & $15.38 \%$ & $7.69 \%$ & $69.23 \%$ & $0.00 \%$ & $7.69 \%$ \\
\hline Total & $\mathbf{1 6 . 6 7 \%}$ & $\mathbf{2 7 . 7 8 \%}$ & $\mathbf{3 8 . 8 9} \%$ & $\mathbf{5 . 5 6 \%}$ & $\mathbf{1 1 . 1 0} \%$ \\
\hline *probability of nonexistence of differences among companies of different size \\
\hline
\end{tabular}

Source: Authors' calculation

Empirical research in developed market economies showed that the companies with the practice of regular preparation of cash flow forecasts and plans have more effective cash- and working capital management (KPMG, 2008). The obtained results suggest that the majority of large companies prepare both alternatives of cash flow statements - planned and realized, while small and medium companies, in most cases, prepare only realized cash flow statements. Reasons for such situation should be sought in more expressed needs of management and higher level of education of professionals in large companies. Among the respondents that do not practice to prepare, either planned or realized cash flow statements are only small companies.

Utilisation the ratios indicating the ability to generate cash, liquidity and turnover is an important part of the cash flow analysis. Respondents were 
Miletić D.: Cash Flow Statement: Assesment of Situation and Application problems in..

able to choose one or more options, and the frequency of utilization of each indicator points out at the incidence of its use among companies depending on their size. The obtained results are presented in Table 3.

Table 3. Utilization of ratios indicating the ability to generate cash, liquidity and turnover $\left(p=0.000^{\star}\right)$

\begin{tabular}{|c|c|c|c|c|c|c|c|c|c|}
\hline $\begin{array}{l}\text { Company } \\
\text { size }\end{array}$ & 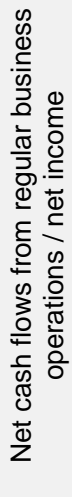 & 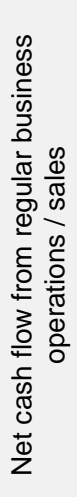 & 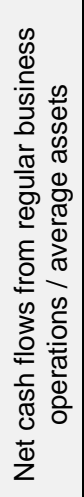 & 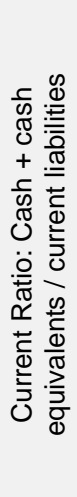 & 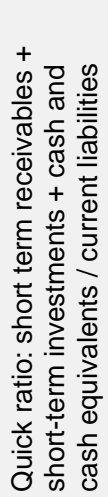 & 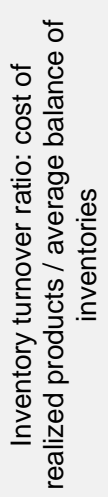 & 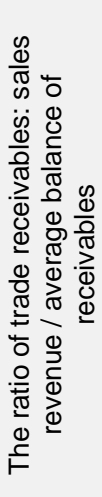 & 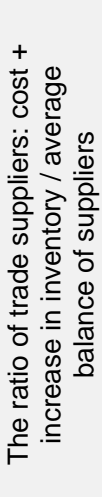 & 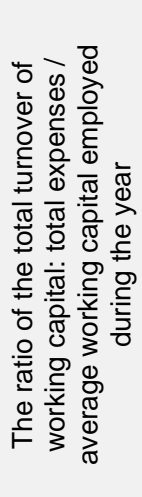 \\
\hline Small & $35 \%$ & $39 \%$ & $9 \%$ & $17 \%$ & $17 \%$ & $30 \%$ & $17 \%$ & $13 \%$ & $13 \%$ \\
\hline Medium & $67 \%$ & $61 \%$ & $56 \%$ & $67 \%$ & $50 \%$ & $34 \%$ & $39 \%$ & $39 \%$ & $28 \%$ \\
\hline Larg & $69 \%$ & $38 \%$ & $15 \%$ & $92 \%$ & $85 \%$ & $38 \%$ & $38 \%$ & $31 \%$ & $38 \%$ \\
\hline Total & $54 \%$ & $46 \%$ & $26 \%$ & $52 \%$ & $44 \%$ & $33 \%$ & $30 \%$ & $26 \%$ & $24 \%$ \\
\hline
\end{tabular}

Source: Authors' calculation

Results indicate that the ratio of cash generating ability (net cash flow/net income), is in average, the most commonly used indicator. It is most widely used among medium companies, while large and especially small businesses use it less frequently. Small legal entities significantly less frequent apply all ratios except inventory turnover ratio. Utilization of current and quick ratio declines with company size decrease. It could be concluded that small legal entities need to improve current practice of financial analysis based on ratio numbers. All four ratios for turnover are less used in comparison to indicators of cash generation and liquidity. This finding suggests that the companies, generally, pay more attention to cash generation and liquidity in comparison to efficiency of individual forms of current assets.

Practice of audits of cash flow statements is an important part of the process of verification of business through confirmation of their financial statements. The frequency of audits indicates the extent to which the auditors actually verify the correctness of cash flow statements, and thus contribute to its affirmation. Results regarding the cash flow statement audit practice are presented in Table 4. 
Miletić D.: Cash Flow Statement: Assesment of Situation and Application problems in..

Table 4. Frequency of audits of cash flow statements $\left(p=0.790^{\star}\right)$

\begin{tabular}{|c|c|c|c|c|}
\hline Company size & Regularly & Not regularly & Newer & Not aware \\
\hline Small & $26.09 \%$ & $8.70 \%$ & $17.39 \%$ & $47.83 \%$ \\
\hline Medium & $50.00 \%$ & $16.67 \%$ & $5.56 \%$ & $27.78 \%$ \\
\hline Large & $92.31 \%$ & $0.00 \%$ & $0.00 \%$ & $7.69 \%$ \\
\hline Total & $\mathbf{5 0 . 0 0 \%}$ & $\mathbf{9 . 2 6} \%$ & $\mathbf{9 . 2 6} \%$ & $\mathbf{3 1 . 4 8} \%$ \\
\hline *probability of nonexistence of differences among companies of different size \\
\hline
\end{tabular}

Source: Authors' calculation

Presented data indicated that half of respondents claimed that the auditors during the audit regularly check cash flow statements. In large companies over $90 \%$ respondents answered that audits are carried out regularly, while in medium and especially small companies, the share of affirmative answers was much lower. In small and medium companies approximately a quarter of respondents answered that audits were not performed regularly or were not performed at all, while in large companies such claims was not given by any respondent. Based on these results, in cases of medium and small companies, auditors should perform more audits of the correctness of preparation of cash flow statements.

In relation to the aforementioned, audit should not be observed only as a tool for validation of correctness of cash flow statement but also as a tool which enables education of the clients by the auditors regarding the cash flow statements, and thus contribute to the affirmation of this financial statement.

Results of testing of hypothesis $\mathrm{H}_{01}(p=0.149), \mathrm{H}_{02}(p=0.133)$ and $\mathrm{H}_{04}(\mathrm{p}=$ 0.790 ).stating respectively that there are no differences in the practice of preparation of cash flow statements throughout the financial year, the practice of preparation of planned- and/or realized cash flow statements and the practice of frequency of audits of cash flow statement in the companies in dependence on their size, indicate that there are not statistically significant reasons for rejection of these hypothesis.

Testing of the hypothesis $\mathrm{H}_{03}$, stating that there are no differences in the practice of utilization of different ratios applicable in the analysis of the ability of generating cash, liquidity and turnover among companies in dependence of their sizes indicates that there are statistically significant reasons to reject this hypothesis $(p=0.000)$. Instead, the alternative hypothesis stating that in practice of utilization of the aforementioned ratios there are significant difference between companies depending on their size, can be adopted. 
Miletić D.: Cash Flow Statement: Assesment of Situation and Application problems in..

\subsection{Causes}

The causes of the current situation in preparation and utilization of cash flow statement have been defined through consideration of issues relating to:

- the attention that management pays to the analysis of liquidity and solvency;

- incentive of management to improve these performances;

- respondents perception of equality and complementarity of the cash flow statement, the balance sheet and income statement;

- perception of management's knowledge about information capabilities of cash flow statements;

- level of practical education of respondents for the preparation cash flow statements in formal education system and

- perception of the major difficulties.

The attention that management pays to the analysis of the liquidity and solvency (Table 5) expresses the general attitude of management on these performances, which definitely motivates management in the use of specific measures and instruments that enable proper and accurate measurement. This is one of the fundamental issues for understanding current situation regarding place and role that cash flows statements should have in financial considerations.

Table 5. The level of attention that management pays to the liquidity and solvency analysis $\left(p=0.133^{\star}\right)$

\begin{tabular}{|c|c|c|c|c|}
\hline Company size & Low & Average & High & Not aware \\
\hline Small & $4 \%$ & $44 \%$ & $52 \%$ & $0 \%$ \\
\hline Medium & $5 \%$ & $50 \%$ & $39 \%$ & $6 \%$ \\
\hline Large & $0 \%$ & $8 \%$ & $85 \%$ & $8 \%$ \\
\hline Total & $\mathbf{3 \%}$ & $\mathbf{3 7 \%}$ & $\mathbf{5 6 \%}$ & $\mathbf{4 \%}$ \\
\hline *probability of nonexistence of differences among companies of different size \\
\hline
\end{tabular}

Source: Authors' calculation

First, regardless of company size, very low proportion of respondents believes that the level of attention paid by the management to the liquidity and solvency analysis is low. The largest proportion of respondents is convinced that managements' attention given to this issue is above average, with majority of respondents from small and large companies with such attitude. Based on these observation it can be concluded that managements mainly have supporting attitudes regarding the importance of the liquidity and solvency. This conclusion undoubtedly points out at the needs of management to have at disposal the high-quality information regarding the liquidity and solvency performance. This is consistent with the conclusions 
Miletić D.: Cash Flow Statement: Assesment of Situation and Application problems in..

from the research performed by Staubus (1989). The question remains if the companies regarding this issue use appropriate measures and instruments. One of the instruments of adequate consideration of the liquidity and solvency is the cash flow statement and the analysis based on it.

Incentives for management as a factor of improvement of cash generation (Table 6) are another crucial factor that contributes to bringing of these performances into the focus of manager's considerations in decision making. Therefore, it is not surprising that in successful companies managers are encouraged to structure assets in a manner that enables their easy conversion into the more liquid forms. Research conducted by well-known consulting and auditing company KPMG points out at the application of cash strategy aimed at creating awareness of management about the proper use of cash in business and the development of so-called "Cash culture". Incentives for managers for improving the liquidity and solvency are part of these strategies (KPMG, 2008).

Table 6. Existence of incentives that stimulate management for structuring of assets and activities in a way that will generate more cash in operations $\left(p=0.149^{\star}\right)$

\begin{tabular}{|c|c|c|c|}
\hline Company size & Exist & Do not exist & Not aware \\
\hline Small & $43.48 \%$ & $21.74 \%$ & $34.78 \%$ \\
\hline Medium & $44.44 \%$ & $38.89 \%$ & $16.67 \%$ \\
\hline Large & $69.23 \%$ & $0.00 \%$ & $30.77 \%$ \\
\hline Total & $\mathbf{5 0 . 0 0 \%}$ & $\mathbf{2 2 . 2 2} \%$ & $\mathbf{3 7 . 7 8 \%}$ \\
\hline${ }^{*}$ probability of nonexistence of differences among companies of different size \\
\hline
\end{tabular}

Source: Authors' calculation

Based on the results the duality of the situation in this regard can be noted. Regardless of company size, about half of respondents emphasized the existence of incentives for management for structuring of assets and activities that will generate more cash. On the other hand, small and medium enterprises in a significant proportion stated that management is not stimulated for this practice. This implies that practices of encouraging management through cash bonuses toward the goals of the liquidity and solvency are not yet predominant in economic practice in Serbia and that this practice should be improved in line with good practice in developed market economies.

The issue of complementarity of cash flow statement with the income statement and balance sheet (Table 7) emphasizes the diversity of cash flow statement in relation to income statement and balance sheet as well as organic connection among them. Respondents' attitude regarding the 
Miletić D.: Cash Flow Statement: Assesment of Situation and Application problems in..

question if cash flow statement supplements balance sheet and income statement or represents unnecessary repetition was examined.

Table 7: Attitude of respondents if the cash flow statement supplements the information provided by the balance sheet and income statement or represents unnecessary repetition $\left(p=0.047^{\star}\right)$

\begin{tabular}{|c|c|c|}
\hline Company size & Supplements & Unnecessary repetition \\
\hline Small & $100.00 \%$ & $0.00 \%$ \\
\hline Medium & $75.00 \%$ & $25.00 \%$ \\
\hline Large & $92.00 \%$ & $8.00 \%$ \\
\hline Total & $\mathbf{8 8 . 0 0 \%}$ & $\mathbf{1 2 . 0 0 \%}$ \\
\hline *probability of nonexistence of differences among companies of different size \\
\hline
\end{tabular}

Source: Authors' calculation

Regardless of the company size the majority of respondents believe that the cash flow statement is of supplementing character, similarly to finding from other countries (Yap, 1997). Such an attitude confirms the understanding of fundamental aspects of equality of cash flows statement in relation to balance sheet and income statement, reflected in their complementarity that makes the whole.

Awareness of management about information capabilities of cash flow statements (Table 8) essentially determines the attitude of management on the usefulness and, consequently, the practical use of this statement in decision making.

Table 8. Awareness of management regarding the cash flow statement information capabilities $\left(p=0.737^{*}\right)$

\begin{tabular}{|c|c|c|c|}
\hline Company size & $\begin{array}{c}\text { Management is } \\
\text { aware }\end{array}$ & Management is not aware & $\begin{array}{c}\text { Respondent is } \\
\text { not aware }\end{array}$ \\
\hline Small & $35 \%$ & $0 \%$ & $65 \%$ \\
\hline Medium & $61 \%$ & $0 \%$ & $39 \%$ \\
\hline Large & $77 \%$ & $8 \%$ & $15 \%$ \\
\hline \multicolumn{2}{|c|}{ Total } & $\mathbf{5 4 \%}$ & $\mathbf{2 \%}$ \\
\hline *probability of nonexistence of differences among companies of different size \\
\hline
\end{tabular}

Source: Authors' calculation

The assumption is that both, the accountants preparing cash flow statements and the decision-makers have to be aware of the information capabilities of cash flow statements in order to put high importance to the analysis of liquidity and solvency and significantly evaluate the performance of cash generating.

Approximately half of the respondents expressed the view that the management is familiar with informational capabilities of the cash flow 
Miletić D.: Cash Flow Statement: Assesment of Situation and Application problems in..

statements. The share of confirmative responses increases from small to large companies. The view that the respondent was not aware of the issue was expressed by approximately another half of respondents with the declining trend from large to small enterprises. Relatively high share of respondents who did not know if management is aware of the information capabilities of cash flow statements provides a basis for the view that managers in practical terms insufficiently use these statements.

Above mentioned statement suggests that the possible solution for improvement regarding identified problem might be the improvement of knowledge and skills of managers, especially of small and medium companies regarding the use and analysis of the of cash flow statements in the decision making.

Level of knowledge and skills of respondents for preparation of cash flow statements obtained from formal education (Table 9) is an essential prerequisite for understanding of the reasons of incomplete and inadequate utilization of cash flow statements.

Table 9. Rating of education during the formal education for practical preparation of cash flow statements? $\left(p=0.000^{\star}\right)$

\begin{tabular}{|c|c|c|c|}
\hline Company size & $\begin{array}{c}\text { Trained practically and } \\
\text { theoretically }\end{array}$ & $\begin{array}{c}\text { Trained only } \\
\text { theoretically }\end{array}$ & Not trained \\
\hline Small & $0.00 \%$ & $56.52 \%$ & $43.48 \%$ \\
\hline Medium & $5.56 \%$ & $50.00 \%$ & $44.44 \%$ \\
\hline Large & $46.15 \%$ & $53.85 \%$ & $0.00 \%$ \\
\hline Total & $\mathbf{1 2 . 9 6 \%}$ & $\mathbf{5 3 . 7 0 \%}$ & $\mathbf{3 3 . 3 4 \%}$ \\
\hline *probability of nonexistence of differences among companies of different size \\
\hline
\end{tabular}

Source: Authors' calculation

There is a statistically significant difference between the legal entities of different sizes $(p=0.000)$ It in terms of practical and theoretical education through the formal education system received by the employees. The structure of responses indicated that more than the half of the respondents expressed the view that during their formal education they were educated only theoretically, while one-third of the respondents mainly from small and medium companies expressed the view that they were not trained at all for practical preparation of cash flow statements. Less than $13 \%$ of the total sample expressed the view that they were educated both practically and theoretically with extremely dominant share of respondents from large companies. This finding suggests that the large companies hire experts with specialized knowledge already gained in the formal education. Also, large legal entities pay more attention to continuous education and certification of knowledge of their employees. 
Miletić D.: Cash Flow Statement: Assesment of Situation and Application problems in..

The structure of responses points out also at the low level of practical education in the existing formal educational system. By the professional schools and colleges for education of economic profiles more care has to be taken, especially in the area of education for practical preparation of cash flow statements and their interpretation.

Consideration of difficulties for frequent preparation of cash flow statements (Table 10) is the sublimation of previous causes of the identified situation.

Table 10. Main difficulties for more frequent preparation of cash flow statements $\left(p=0.781^{\star}\right)$

\begin{tabular}{|c|c|c|c|c|c|}
\hline $\begin{array}{c}\text { Company } \\
\text { size }\end{array}$ & $\begin{array}{c}\text { Insufficiently } \\
\text { sophisticated } \\
\text { accounting } \\
\text { software }\end{array}$ & $\begin{array}{c}\text { Insufficiently } \\
\text { developed } \\
\text { supporting } \\
\text { records }\end{array}$ & $\begin{array}{c}\text { Insufficient } \\
\text { knowledge of } \\
\text { methodology } \\
\text { of preparation }\end{array}$ & $\begin{array}{c}\text { Management } \\
\text { does not require } \\
\text { more frequent } \\
\text { preparation }\end{array}$ & Other \\
\hline Small & $26 \%$ & $22 \%$ & $35 \%$ & $30 \%$ & $13 \%$ \\
\hline Medium & $33 \%$ & $22 \%$ & $28 \%$ & $11 \%$ & $33 \%$ \\
\hline Large & $69 \%$ & $61 \%$ & $17 \%$ & $15 \%$ & $8 \%$ \\
\hline \multicolumn{7}{|c|}{ Total } & $39 \%$ & $31 \%$ & $\mathbf{3 1 \%}$ & $\mathbf{2 0 \%}$ & $\mathbf{1 8 \%}$ \\
\hline *probability of nonexistence of differences among companies of different size & \\
\hline
\end{tabular}

Source: Authors' calculation

As a major problem for more frequent preparation of cash flow statements insufficiently sophisticated accounting software can be identified. It is followed by the difficulties related to insufficiently developed supporting records and insufficient knowledge of the methodology of preparation of cash flow statements. The fact that management does not require more frequent preparation of cash flow statements is rarely seen as a difficulty.

The general conclusion is that managements must comprehensively organize system of financial reporting on a cash basis. First, technical and human prerequisites for obtaining valid information have to be created. This includes the introduction of appropriate software that can generate cash transactions for similar groups of financial activities - operating, investing and financing. Staff engaged in these fields must acquire the methodology of preparation and knowledge of cash flow analysis based on the cash flow statements. Connected to this is the organization of recording and input of data into the software for cash flow statements generating. This is important and requires a comprehensive knowledge of business and especially of cash transactions that have an impact on the liquidity of the enterprise. At the end, equaly important is the commitment of management to establishment of such system and to its improvement over time with creating of connections with other information sources from the accounting system. This creates the basis for main product of accounting-essential and timely prepared information. 
Miletić D.: Cash Flow Statement: Assesment of Situation and Application problems in..

\section{Conclusion}

Based on the conducted research and analysis of the received responses, the situation on cash flow statement preparation and utilization in Serbia is described and the causes of the current situation are explained, in dependence of the company size.

Generally, it can be concluded that a significant proportion of companies, including small and medium ones, prepare cash flow statements throughout the year for purposes of internal financial reporting. Most large companies prepare cash flow statements as planned as well as realized, while medium and especially small businesses, in most cases, prepare only realized cash flow statements.

Results indicate that the companies more frequently use ratios of cash generation and liquidity compared to ratios of effectiveness of certain forms of current assets.

Concerning the regularity of audits of cash flow statements, in large companies audits are more regular than in the medium and small ones, pointing out at the need for enhancement of educational role of auditors in medium and small companies.

Based on obtained results managements has very positive attitudes towards the importance of liquidity and solvency and highly ranked the importance of analyzing of these performances. The practice of management incentives for achieving the objectives of liquidity and solvency through structuring of company assets into appropriate forms exists, but it is not yet the predominant in local economic practice.

The understanding of fundamental aspects of equality of statements of cash flows in relation to balance sheet and income statement reflected in their complementarity is the prevailing attitude.

Management is partially familiar with the information capabilities of cash flow statements but there is an evident lack of practical training for the preparation of cash flow statements in formal education programs.

As the main difficulty for more frequent preparation of cash flow statements insufficiently sophisticated accounting software can be emphasized followed with insufficiently developed supporting records and insufficient knowledge of the methodology of preparation of cash flow statements. The fact that management does not require frequent preparation of cash flow statements is less expressed as the difficulty.

The possibilities for improvement of identified situation regarding the preparation and utilization of cash flow statements are primarily recognized in 
Miletić D.: Cash Flow Statement: Assesment of Situation and Application problems in..

education of managers and accountants either through formal training programs, or through the system of lifelong learning.

Based on statistical analysis it can be stated that the situation in the design, analysis and implementation of cash flow statements partially distinguishes between companies in dependence of their size. The differences were noted primarily with regard to practice of using of various ratios in business analysis by companies and to the level of practical knowledge regarding cash flow statement preparation as the criterion for selection of employees.

\section{Reference}

Alihodžić, A. (2013). Analysis of change in net income and free cash flow for shares in B\&H capital market. Tržište, novac, kapital, 46(3), 22-36.

Boussard, D., \& Colasse, B. (1992). Funds-flow statements and cash-flow accounting in France Evolution and significance. European Accounting Review, 1(2), 229254. Retrieved from Business Source Premier, EBSCOhost.

Broome, O. W. (2004). Statement of Cash Flows: Time for Change! Financial Analysts Journal of CFA Institute, 60(2), 16-22. Retrieved from http://www.cfapubs.org/toc/faj/2004/60/2.

Cheng, C. S. A., \& Hollie, D. (2008). Do core and non-core cash flows from operations persist differentially in predicting future cash flows? Review of Quantitative Finance and Accounting 31(1), 29-53. Retrieved from http://link.springer.com/article/10.1007/s11156-007-0062-7/fulltext.html

Đukić, T., \& Trajčevski, M. (2012). Financial reporting on the cash flow in the cement industry factories in Serbia. Teme, 36(1), 153-170. Retrieved from http://teme.junis.ni.ac.rs/teme1-2012/teme\%201-2012-09\%20lat.pdf

Hales, J., \& Orpurt, F. S. (2013). A Review of Academic Research on the Reporting of Cash Flows from Operations. Accounting Horizons, 27(3), 539-578. doi: 10.2308/acch-50498

KPMG Canada. (2008). Clawing Back Cash: Developing a Total Cash Management Strategy. KPMG's Restructuring Services group commissioned mergermarket to survey executives at mid-sized organisations around Asia Pacific. Retrieved from https://www.kpmg.com/AU/en/IssuesAndInsights/ArticlesPublications/Documents IClawing-back-cash-Developing-a-total-cash-management-strategy.pdf

KPMG Canada. (2008). The importance of preserving cash in a downturn: a report prepared by CFO Europe Research in colaboration with KPMG. Retrieved from https://www.kpmg.com/LU/en/IssuesAndInsights/Articlespublications/Documents/ Preserving-cash-in-downturn-kpmg.pdf

Lukač, D. (2013). Izveštaj o tokovima gotovine: informaciona moć i rizici. Računovodstvo, 57(9-10), 3-17.

Miletić, D. (2011). Direktan i indirektan metod sastavljanja izveštaja o tokovima gotovine iz poslovnih aktivnosti - komparativan pristup. Računovodstvo, 55(1112), 75-86. 
Miletić D.: Cash Flow Statement: Assesment of Situation and Application problems in..

Ohlson, A. J., \& Aier, K. J. (2009). On the Analysis of Firm's Cash Flows. Contemporary Accounting Research, 26(4), 1091-1114. doi:10.1506/car.26.4.4

Orpurt, F. S., \& Zang, Y. (2009). Do Direct Cash Flow Disclosures Help Predict Future Operating Cash Flows and Earnings? The Accounting Review, 84(3), 893-935. doi: 10.2308/accr.2009.84.3.893

Slavković, G., \& Bugarin, M. (2011). Economic cash flow and decision of investment in mining. Inovacije i razvoj, (1), 59-64.

Staubus, J. G. (1989). Cash Flow Accounting and Liquidity: Cash Flow Potential and Wealth. Accounting and Business Research, 19(74), 161-169. Retrieved from Business Source Premier, EBSCOhost.

Stevanović S. (2013). Classification of cash flows: Dilemmas in international and domestic practices. Računovodstvo, 57(3-4), 30-37.

Stevanović, S., Belopavlović, G., \& Lazarević-Moravčević, M. (2013). Creative cash flow reporting: The motivation and opportunities. Economic Analysis, 46(1-2), 2839.

Vlaović-Begović, S., Momčilović, M., \& Jovin, S. (2013). Advantages and limitations of the discounted cash flow to firm valuation. Škola biznisa, (1), 38-47. Retrieved from http://scindeks-clanci.ceon.rs/data/pdf/1451-6551/2013/145165511301038V.pdf

Yap, C. (1997). User' perceptions of the need for cash flow statements - Australian evidence. European Accounting Review, 6(4), 653-672. doi: 10.1080/09638189700000006 